\title{
PEMBENTUKAN KARAKTER POSITIF PESERTA DIDIK MELALUI BIMBINGAN PRIBADI SOSIAL
}

\author{
Fathorrahman Z \& Siti Farida \\ STAI Nazhatut Thullab Sampang \\ e-mail: rahmanzfathorbarokah@gmail.com
}

\begin{abstract}
Abstrak:
Tulisan ini membahas tentang pembentukan karakter positif peserta didik, hal ini dilatar belakangi oleh buruknya karakter masyarakat kita dewasa ini yang disinyalir oleh beberapa kalangan bahwa hal tersebut disebabkan arus globalisasi, teknologi dan informasi yang begitu pesat sehingga berdampak pada merosotnya moral, nila-nilai sosial, budaya dan bahkan agama. Pembentukan karakter positif pada peseta didik di sekolah melalui bimbingan pribadi sosial dapat dilakukan melalui beberapa teknik, yaitu bimbingan klasikal, kelompok, dan individual dengan memperhatikan beberapa aspek; aspek psikologis siswa sebagai remaja, budaya lokal, dan kondisi masyarakat serta melakukan kerja sama yang sinergis antara guru bimbingan dan konseling dengan semua elemen yang ada di sekolah, orang tua siswa, dan masyarakat agar tujuan layanan bimbingan pribadi sosial dapat tercapai.
\end{abstract}

Kata Kunci: Karakter, Bimbingan Pribadi Sosial

\begin{abstract}
:
This paper discusses abaout the formation of positive character of students, this is due to the bad character of our society today that is allegedly by some realm that is caused by the flow of globalization, technology and information so rapidly so that it has the impact decline of moral, social values, culture and also religion. The formation of positive characters to student in the school by guidance of personal social counseling can do it pass through several techniques, namely classical, group, and individual guidance with attention to several aspects; the psychological aspects of students as adolescents, local cultures, and communities condition as well as synergistic collaboration between guidance and counseling teachers with all elements which present in schools, parents, and communities in order that the goals of personal social guidance services can be achieved.
\end{abstract}

Keywords: Character, Personal Social Guidance. 


\section{Pendahuluan}

Perkembangan ilmu pengetahuan, teknologi, transportasi dan informasi yang semakin canggih serta derasnya arus globalisasi telah merambah hingga ke pelosok Nusantara yang salah-satu indikasinya adalah hampir tidak ada sejengkalpun dari tanah air yang tidak tersentuh oleh kemajuan tersebut. Hal ini berimplikasi pada mudahnya akses komunikasi, informasi dan transportasi sehingga lahir sebuah loncatan sejarah yang luar biasa dalam perkembangan peradaban umat manusia.

Kemajuan tersebut perlu disyukuri dan disikapi secara dewasa, karena diakui atau tidak, hal tersebut di samping bermanfaat sebagai suatu perangkat dalam membantu kehidupan manusia, juga telah berdampak pada merosotnya nilai-nilai spiritual dan moral serta bergesernya nilai-nilai sosial yang sebelumnya telah lama terpatri di hati masyarakat, bahkan ironisnya, mereka umumnya telah terjerembab pada paham pragmatisme yang hanya mengejar kepuasan duniawi secara tidak bertanggung jawab dengan menghalalkan segala cara bahkan menafikan nilai-nilai sosial maupun agama. Dari parahnya kondisi ini, agaknya tidak terlalu berlebihan jika dikatakan bahwa "Orang bodoh (tidak berpendidikan) jadi maling atau rampok, sedangkan orang pintar (berpendidikan) jadi koruptor". Hal tersebut terbukti dengan semakin tingginya pelanggaran HAM, dekadensi moral, korupsi, kolusi, nepotisme, kriminal, perampokan, pencurian, pelecehan seksual terhadap anak di bawah umur, prostitusi, penyalah gunaan narkoba, miras dan lain sebagainya. Persoalan yang tak kalah peliknya juga adalah terjadinya beberapa pelanggaran di dalam dunia pendidikan seperti menyontek, plagiatisme sampai jual beli kunci jawaban soal Ujian Nasional.

Fenomena-fenomena di atas disinyalir penyebabnya adalah karena buruknya karakter bangsa yang telah jauh meninggalkan nilai-nilai agama, sosial, dan budaya. Oleh karena itu, pembentukan karakter yang positif merupakan suatu keniscayaan yang harus diimplementasikan di lembaga-lembaga pendidikan. Pendidikan idealnya merupakan salah satu faktor yang sangat penting dalam kehidupan manusia, karena dengan pendidikan seseorang dapat mengembangkan potensi yang ada pada dirinya dan dapat membentuk pribadi yang bertanggungjawab, cerdas dan kreatif. Pendidikan seyogyanya tidak hanya akan melahirkan output anak didik yang cerdas intelektual, menjadi ilmuwan, pengusaha, politikus dan lain sebagainya, Akan tetapi juga cerdas spiritual, memiliki akhlak serta karakter yang baik (positif).

\section{Pengertian dan Konsep Karakter}

Dalam kamus umum bahasa Indonesia, karakter diartikan sebagai tabiat; watak; sifat-sifat kejiwaan; akhlak; atau budi pekerti yang membedakan seseorang dari pada yang lainnya. ${ }^{1}$ Maka karakter dapat artikan sebagai watak, tabiat, atau akhlak seseorang yang membedakan secara kualitas antara seseorang dengan yang lainnya.

Para ahli mempunyai pendapat yang berbeda tentang karakter walaupun sebenarnya memiliki substansi yang sama. Sebagaimana yang diungkapkan oleh Scerenko, karakter dimaknai sebagai atribut atau ciri-ciri yang membentuk dan

1 W.J.S. Poerwadarminta, Kamus Umum Bahasa Indonesia (Jakarta: Balai Pustaka, 2005), 521. 
membedakan ciri pribadi, ciri etis dan kompleksitas mental dari seseorang, suatu kelompok atau bangsa. ${ }^{2}$ Dengan demikian, dapat dipahami bahwa karakter merupakan sebuah identitas yang melekat pada kualitas tindakan atau perilaku seseorang yang terjadi secara spontanitas sekaligus menjadi ciri khas bagi masingmasing individu yang bersumber pada hasil pengetahuan, perenungan, pemikiran dan kesadaran akan nilai-nilai mulia yang terkandung dalam norma-norma agama, hukum tatakrama, budaya, adat istiadat dan estetika.

Wacana mengenai pendidikan karakter yang memposisikan moralitas dan spiritualitas (nilai-nilai agama) ibarat dua mata uang yang tidak dapat dipisahkan antara keduanya, yaitu moral dan nilai-nilai spiritual memiliki peran yang sangat urgen dalam membangun peradaban manusia.

Dalam pendidikan Islam, karakter diidentikkan dengan pendidikan nilai, yaitu akhlak, adab dan keteladanan. Akhlak merujuk pada tugas dan tanggung jawab selain syari'ah dan ajaran agama secara umum, sedangkan adab merujuk pada sikap yang dihubungkan dengan tingah laku yang baik. Sedangkan keteladanan merujuk pada kualitas karakter yang ditampilkan oleh seseorang (Muslim) dengan cara meneladani Nabi Muhammad SAW. ${ }^{3}$

Walaupun identik, pendidikan karakter dalam agama (Islam) memiliki keunikan dan ciri khas yang berbeda dengan pendidikan di dunia Barat. ${ }^{4}$ Perbedaan yang mencolok terletak pada penekanan terhadap prinsip-prinsip agama yang abadi, aturan dan hukum dalam moralitas, pemahaman tentang kebenaran, penolakan terhadap otonomi moral sebagai tujuan pendidikan moral dan penekanan pahala serta penghambaan diri kepada sang Khalik sebagai motivasi perilaku berkarakter. Inti perbedaan-perbedaan ini terletak pada keberadaan wahyu Ilahi sebagai sumber dan rambu-rambu pendidikan karakter.

Beberapa hal yang perlu ditinjau ulang dalam konsep pendidikan karakter versi barat adalah adanya pemisahan secara teoritis antara pendidikan agama dan pendidikan karakter dalam lembaga pendidikan. Salah satu contohnya adalah ungkapan bahwa kehidupan religius seseorang merupakan urusan antara individu dengan Tuhannya sebuah pemahaman tentang kehidupan agama yang keliru, padahal kehidupan beragama justru dapat dijadikan pondasi yang kokoh bagi pelaksanaan pendidikan karakter dalam mengaplikasikan niai-nilai moral yag diyakini sebagai perintah Tuhan.

Pembahasan di atas menggambarkan betapa luas, karya dan mulianya nilainilai karakter. Hal ini berarti bahwa Indonesia sebagai bangsa serta negara yang berasaskan atas dasar ke-Tuhanan, yang bermartabat, bermoral dan berbudi pekerti luhur yang melaksanakan kegiatan belajar mengajar di lembaga-lembaga pendidikan, baik negeri maupun swasta yang berada di bawah naungan kementerian agama maupun kementerian pendidikan dan kebudayaan memiliki tugas yang cukup berat untuk memformulasikan nilai-nilai karakter yang baik.

\footnotetext{
2 Linda C. Scerenko, Values and Character Education Implementation Guide (Gerogia: Departement of Education, 1997), 210.

${ }^{3}$ Abdul Majid dan Dian Andayanik, Pendidikan Karakter Persepektif Islam, (Bandung: PT. Rosda Karya, 2012), 52. Dalam Q.S. Al-Ahzab ayat 21 dan Hadits riwayat Ahmad, "Sesungguhnya aku (Muhammad) diutus tidak lain adalah untuk menyempurnakan akhlak budi pekerti mulia".

${ }^{4}$ Dony Koesoema, Pendidikan Karakter, (Jakarta: Kompas Gramedia, 2007), 250.
} 


\section{Pendidikan Karakter}

Pendidikan karakter merupakan sebuah istilah yang akhir-akhir ini semakin mendapatkan pengakuan di hati masyarakat Indonesia, terlebih setelah Kementerian Pendidikan dan Kebudayaan secara nyata memasukkan pendidikan karakter dalam Desain Induk Pembangunan Karakter Bangsa 2010-2025..$^{5}$ Hal ini tidak terlepas dari adanya berbagai ketimpangan yang dirasakan kalangan masyarakat terkait dengan output dari pendidikan formal yang belum maksimal, seperti merebaknya kasus korupsi yang dilakukan oleh oknum pejabat yang notabene adalah lulusan perguruan tinggi ternama di Negeri ini.

Pendidikan karakter dapat dimaknai sebagai hal-hal positif yang dilakukan seorang guru dan berpengaruh kepada karakter siswa yang diajarnya. Winton memaknai pendidikan karakter sebagai upaya sadar dan sungguh-sungguh dari seorang guru untuk mengajarkan nilai-nilai kepada siswanya. ${ }^{6}$ Ujung tombak kesuksesan dari sebuah proses pendidikan terletak pada guru dalam memainkan peran dan melaksanakan tugas-tugasnya guna mengantarkan peserta didik ke arah tujuan yang telah ditetapkan. Terkait dengan sosok guru sebagai agent of change, Munif Chatib mengatakan bahwa kualitas pembelajaran bergantung pada kualitas para guru yang mampu membimbing siswanya ke arah perubahan yang baik yaitu mengubah siswanya dari negatif menjadi positif tanpa harus mempermasalahkan input siswa tersebut. ${ }^{7}$

Pendidikan karakter merupakan sebuah upaya pergerakan di bidang pendidikan yang mendukung pengembangan sosial, pengembangan emosional dan pengembangan etika para peserta didik. Upaya proaktif yang dilakukan pihak pemerintah maupun penyelenggara pendidikan formal, non formal ataupun informal mengembangkan inti pokok dari nilai-nilai etik dan nilai-nilai kinerja, seperti kepedulian, kejujuran, keuletan dan ketabahan, tanggung jawab, menghargai diri sendiri dan orang lain.

Dari uraian tersebut, dapat dipahami bahwa pendidikan karakter adalah proses pemberian tuntunan kepada peserta didik untuk menjadi manusia seutuhnya yang berkarakter dalam dimensi hati, fikir, raga, serta rasa dan karsa. Atau pendidikan karakter dapat juga dimaknai sebagai pendidikan nilai budi pekerti, pendidikan moral, pendidikan watak yang bertujuan mengembangkan kemampuan peserta didik untuk memberikan keputusan baik-buruk, memelihara sesuatu yang baik dan mewujudkan kebaikan dalam kehidupan sehari-sehari dengan sepenuh hati.

\section{Strategi dan Proses Pembentukan Karakter}

Ada tiga lingkungan pendidikan yang sangat strategis dalam membentuk karakter seseorang (anak didik), yaitu: lingkungan keluarga, sekolah dan masyarakat. Agar dapat membentuk karakter peserta didik sesesuai yang

\footnotetext{
${ }^{5}$ Fatchul Mu'in, Pendidikan Karakter Konstruksi Teoritik \& Praktik, (Yogyakarta: Ar-Ruzz Media, 2011), 67. atau lihat dalam Taufik Hanafi Human Development Approach for Planning and Monitoring. Director for Education and Religious Affairs BAPPENAS ARAHAN RPJPN 2005-2025, hal. 2.

${ }^{6}$ Sue Winton, Character Education: Implication for Critical Democracy, International Critical Childhood Policy Studies, Vol. I (I), 2008.

${ }^{7}$ Munif Chatib, Sekolahnya Manusia, (Bandung: Mizan, 2011), 93.
} 
diinginkan, maka dibutuhkan beberapa strategi yang dapat diimplementasikan di tiga lingkungan pendidikan tersebut.

Proses pembentukan karakter terdiri dari tiga taraf, yaitu: pertama, pengetahuan atau pemahaman. Tujuannya untuk memberikan informasi kepada peserta didik agar mengetahui yang baik dan yang buruk, atau memberi kecakapan berbuat dan mengucapkan sesuatu (pengetahuan hafalan). Kedua, mempunyai perasaan sadar. Jadi apabila seseorang melakukan aktifitas yang ia sadari maka termasuk proses pembentukan karakter. Begitu juga dengan sebaliknya, yaitu apabila seseorang melakukan perbuatan tanpa ia sadari maka bukan bagian dari proses pembentukan karakter. Ketiga, bebas untuk melakukan dan bebas untuk tidak melakukan suatu perbuatan (tidak ada paksaan dari pihak manapun). ${ }^{8}$

Selanjutnya, berdasarkan desain utama yang dikembangkan oleh Kemendiknas (2010), secara psikologis dan sosial kultural pembentukan karakter dalam diri individu merupakan fungsi diri seluruh potensi individu manusia, baik dalam aspek kognitif, afektif maupun psikomotorik dalam konteks interaksi sosial kultural; dalam keluarga, sekolah dan masyarakat yang berlangsung sepanjang hayat.

Maka dapat dipahami bahwa pendidikan merupakan salah satu strategi dasar dari pembangunan karakter bangsa yang dalam pelaksanaannya harus dilakukan secara koheren dengan beberapa strategi, yang mencakup sosialisasi, pemberdayaan, pembudayaan dan kerja sama seluruh komponen bangsa. Pembangunan karakter dilakukan dengan pendekatan sistematik dan integratif dengan melibatkan keluarga, satuan pendidikan, masyarakat sipil, anggota legislatif, media massa, dunia usaha dan duni industri.

Agar pembentukan karakter dapat direalisasikan sebagaimana yang diidealkan, maka pelaksanaan pendidikan karakter harus diimplementasikan secara baik. Untuk itu ada beberapa hal yang harus dilakukan, yaitu; 1) keteladanan dari guru pengampu mata pelajaran, karyawan, pimpinan, dan para pemangku kebijakan di sekolah, 2) pendidikan karakter dilakukan secara konsisten dan terus menerus, dan 3) penanaman nilai-nilai karakter utama.

Nilai karakter juga harus ditumbuhkan melalui proses pembiasaan dalam keseharian (habituasi), melalui budaya sekolah (school culture), karena hal tersebut merupakan kunci dari keberhasilan pendidikan karakter. ${ }^{9}$

Proses pendidikan karakter didasarkan pada totalitas psikologis yang mencakup seluruh potensi individu manusia (kognitif, afektif dan psikomotorik) serta fungsi totalitas sosiokultural sebagai internalisasi pendidikan.

Konfigurasi karakter dalam konteks totalitas proses psikologis sosiokultural dapat dikelompokkan dalam: 1) olah hati (spiritual and emotional development), 2) olah pikir (intellectual development), 3) olah raga dan kinestik (physical \& kinesthetic development) 4) olah rasa dan karsa (affective and creativiy development). Proses tersebut secara holistik dan koheren memiliki saling keterkaitan dan saling melengkapi yang terkandung masing-masing di dalam nilainilai keutamaan.

\footnotetext{
${ }^{8}$ Catatan mata kuliah: Filsafat Pendidikan Islam, jurusan Manajemen dan Kebijakan Pendidikan Islam, UIN SUKA Yogyakara, 13 Maret 2012, oleh Prof. Dr. H. Maragustam, M.A.

${ }^{9}$ Novan Ardy Wiyani, Manajemen Pendidikan Karakter, Konsep dan Implementasinya di Sekolah (Yogyakarta: Pustaka Insan Madani, 2010), 44.
} 
Selanjutnya, pembentukan karakter dapat dilakukan melalui 3 (tiga) desain, yaitu: 1) desain berbasis kelas, yang berbasis pada relasi guru sebagai pendidik dan siswa sebagai peserta didik; 2) desain berbasis kultur sekolah, yang berusaha membangun kultur sekolah yang mampu membentuk karakter anak didik dengan bantuan pranata sosial sekolah agar nilai-nilai tertentu terbentuk dan menjadi ruh dalam diri peserta didik, dan 3) desain berbasis komunitas. ${ }^{10}$

Pembentukan karakter haruslah melibatkan semua pihak, baik kehidupan dalam rumah tangga sekeluarga, sekolah, lingkungan lebih luas (masyarakat) atau bahkan Negara. Karena itu, mensinerjikan relasi yang nyaris terputus antara ketiga lingkungan pendidikan inilah pertama-pertama yang harus dilakukan.11

Berdasarkan uraian di atas, maka untuk membentuk karakter anak didik haruslah melibatkan beberapa pihak, yaitu: menjalin komunikasi dan kerja sama yang baik antara pihak keluarga, masyarakat, ataupun lembaga pendidikan yaitu sekolah/ madrasah. Khusus di sekolah/ madrasah, pembentukan karakter harus diintegrasikan ke dalam semua mata pelajaran (intra) dan melalui berbagai kegiatan ekstrakurikuler, antara lain: Organisasi Siswa Inta Sekolah (OSIS), pramuka, kesenian, olah raga, PMR, budaya sekolah dan lain-lain.

Menurut Maragustam, ada sepuluh pilar karakter yaitu:

a. Spiritual keagamaan

b. Tanggung jawab, integritas dan kemandirian

c. Kejujuran dan amanah

d. Bersahabat/ komunikasi (silaturrahmi) yang sejuk, kerja sama, demokratis dan peduli

e. Percaya diri, keyakinan, kreatif, pekerja keras dan pantang menyerah

f. Disiplin dan teguh pendirian (istiqomah) dalam mencari jalan keluar dari berbagai masalah.

g. Berperilaku baik, sabar, hidup dengan cita-cita dan rendah hati

h. Menjadi teladan dalam hidup

i. $\quad$ Toleransi (tasamuh)

j. $\quad$ Semangat ${ }^{12}$

Pembentukan karakter memerlukan sebuah proses yang simultan dan berkesinambungan. Oleh karenanya sepuluh pilar karakter di atas hendaknya diimplementasikan dalam lingkungan keluarga, masyarakat dan pendidikan Baik formal, informal manupun nonformal yang melibatkan aspek membelajarkan habituasi (pembiasaan), knowing the good (mengetahui hal yang baik), feeling the good (merasakan hal yang baik), acting the good (melakukan kebaikan), keteladanan, dan tobat. Materi pendidikannya tidak terbatas pada hal-hal yang bersifat afektif, tetapi juga yang berkaitan dengan kognitif dan psikomotorik. ${ }^{13}$

\footnotetext{
10 Novan Ardy Wiyani, Manajemen Pendidikan Karakter, Konsep dan Implementasinya di Sekolah, (Yogyakarta: Pustaka Insan Madani, 2010), 46.

11 Suyanto \& Djihad Hisyam, Pendidikan di Indonesia Memasuki Melenium III, (Yogyakarta: Adicita Karya Nusa, 2000), 186-187.

12 Pidato ilmiah dalam acara pengukuhan guru besar Maragustam, di rapat senat terbuka Univirsitas Islam Negeri Sunan Kalijaga Yogyakarta. Tanggal 23 Oktober 2012.

13 Maragustam Siregar, Mencetak Pembelajar Menjadi Insan Paripurna: Falsafah Pendidikan Islam, (Yogyakarta: Nuha Litera, 2010), 126-127.
} 


\section{Tujuan Pendidikan Karakter dalam Konteks Pendidikan Nasional}

Berdasarkan fungsi dan tujuan Pendidikan Nasional menurut UUSPN No. 20 tahun 2003 bab 2 pasal 3, disebutkan bahwa: Pendidikan Nasional Pasal 3 mengamanatkan bahwa pendidikan nasional berfungsi mengembangkan kemampuan dan membentuk watak serta peradaban bangsa yang bermartabat dalam rangka mencerdaskan kehidupan bangsa, bertujuan untuk berkembangnya potensi peserta didik agar menjadi manusia yang beriman dan bertakwa kepada Tuhan Yang Maha Esa, berakhlak mulia, sehat, berilmu, cakap, kreatif, mandiri, dan menjadi warga negara yang demokratis serta bertanggung jawab. ${ }^{14}$

Berdasarkan fungsi Pendidikan Nasional tersebut, institusi pendidikan hendaknya mampu memberikan pencerahan yang berdampak positif pada watak maupun karakter bangsa. Fungsi ini sungguh terasa amat berat terutama jika dikaitkan dengan siapa yang bertanggung jawab untuk keberlangsungan fungsi tersebut.

Untuk merealisasikan fungsi di atas, pemerintah mencanangkan gerakan nasional melalui pendidikan karakter dalam seting sekolah untuk mempermudah kontrol dan pengawasannya. Pendidikan karakter berbasis sekolah memilik beberapa fungsi, salah satunya adalah: "mengembangkan kemampuan", dapat dipahami bahwa pendidikan nasional menganut aliran konstruktivisme yang mempercayai bahwa peserta didik adalah manusia yang potensial dan dapat dikembangkan secara optimal melalui proses pendidikan. Artinya, setiap layanan pendidikan yang ada di Indonesia harus dipersepsi secara sama bahwa peserta didik memiliki potensi yang luar biasa dan perlu difasilitasi melalui proses pendidikan untuk mengebangkan potensinya. Meski demikian, kemampuan yang dimaksud belum tersirat secara jelas apakah mengenai pembentukan watak, kemampuan akademik, kemampuan sosial, atau kemampuan religi. Hal ini belum dapat dipahami secara jelas pernyataan UUSPN tersebut.

Dalam konteks ke-Indonesiaan, pendidikan karakter dapat dipahami sebagai kemampuan yang harus dikembangkan pada peserta didik oleh penyelenggara pendidikan. Kemampuan tersebut akan menjadikan manusia sebagai makhluk yang ber-Ketuhanan (tunduk dan patuh pada konsep ketuhanan) dan mengemban amanah sebagai pemimpin di dunia (khalifah fi al-ardi). Kemampuan yang perlu dikembangkan pada peserta didik di Indonesia adalah kemampuan mengabdi pada Tuhan yang menciptakannya, kemampuan untuk menjadi dirinya sendiri, kemampuan untuk hidup secara harmonis dengan manusia dan makhluk lainnya, dan kemampuan menjadikan alam semesta ini sebagai wahan kemakmuran dan kesejahteraan bersama.

Selanjutnya fungsi "membentuk karakter" mengandung makna bahwa pendidikan nasional harus diarahkan pada pembentukan watak. Pendidikan berorientasi pada watak peserta didik sudah merupakan suatu hal yang tepat, akan tetapi masih perlu dipertegas mengenai istilah "perlukan" terhadap watak. Apakah watak tersebut harus dikembangkan, dibentuk atau difasilitasi?. Perspektif pedagogik lebih memandang bawah pendidikan adalah mengembangkan, menguatkan atau menfasilitasi watak dan bukan membentuk watak. Hal tersebut dikarenakan jika watak dibentuk maka tidak ada lagi proses pedagogik/

14 Undang-Undang tentang Sistem Pendidikan Nasional, No. 20 Tahun 2003. 
pendidikan, yang terjadi adalah pengajaran. Ia memandang dan mensyaratkan untuk terjadinya proses pendidikan yang terdapat kebebasan peserta didik sebagai subyek didik bukan obyek. Jika peserta didik diposisikan sebagai obyek, maka hal ini tentu bertolak belakang dengan fungsi pendidikan, yaitu mengembangkan kemampuan yang dilandasi oleh pandangan konstruktivisme.

Sedangkan fungsi berikutnya adalah "peradaban bangsa". Dalam spektrum pendidikan nasional, pendidikan selalu dikaitkan dengan pembangunan bangsa Indonesia sebagai satu bangsa, yaitu pendidikan harus mampu untuk menjadikan tiap-tiap individu bangsa menjadi insan terdidik, bermartabat dan berada, hal ini membutuhkan waktu yang tidak singkat. Dengan demikian, bangsa yang beradab merupakan dampak dari pendidikan yang menghasilkan manusia terdidik.

Rumusan Tujuan Pendidikan Nasional dalam UU Sisdiknas mengandung filosofi bahwa pendidikan sebagai educare yang lebih cenderung mengajar, melatih, melengkapi peserta didik dengan pengetahuan dan keterampilan menekankan pada proses pemberian materi ajar serta sistem penilaian yang baku dan kaku perlu untuk disempurnakan kembali. Proses pendidikan dalam tahap selesai dengan hasil ujian dan selesainnya pemberian materi dan cenderung mengabaikan penekanan terhadap karakter mulia yang menjadi kepribadian peserta didik. Bentuk simplifikasi (penyederhanaannya) adalah bahwa proses pendidikan terhadap tujuan mulia pendidikan tersebut sangat bertolak belakang dengan perilaku nyata peserta didik maupun output lembaga pendidikan.

Sunaryo Kartadinata menegaskan bahwa ukuran keberhasilan pendidikan yang berhenti pada angka ujian sebagaimana Ujian Nasional, adalah sebuah kemunduran, karena pembelajaran hanya menjadi proses untuk menguasai keterampilan dan mengakumulasikan pengetahuan. Statemen yang demikian menempatkan peserta didik sebagai pelajar imitative dan belajar dari eksposeekspose didaktis yang akan berhenti pada penguasaan fakta, prinsip dan aplikasinya. Hal ini tidak sesuai dengan amanat pendidikan yang digariskan dalam UU Sisdiknas. ${ }^{15}$

Pendidikan karakter dalam seting sebuah lembaga pendidikan memiliki tujuan sebagai berikut:

a. Menguatkan dan mengembangkan nilai-nilai kehidupan yang dianggap penting dan perlu sehingga menjadi kepribadian/ kepemilikan peserta didik yang khas sebagaimana nilai-nilai yang dikembangkan

b. Mengoreksi perilaku peserta didik yang tidak sesuai dengan nilai-nilai yang dikembangkan oleh penyelenggara pendidikan

c. Membangun hubungan yang harmonis dengan keluarga dan masyarakat dalam memerankan tanggung jawab pendidikan karakter secara bersama. ${ }^{16}$

Berdasarkan tujuan-tujuan pendidikan karakter di atas, maka dapat diasumsikan bahwa, pertama: penguasaan akademik diposisikan sebagai media atau sarana untuk mencapai tujuan penguatan dan pengembangan karakter. Hal ini berimplikasi bahwa proses pendidikan karakter harus dilaksanakan secara

\footnotetext{
${ }^{15}$ Sunaryo Kartadinata, Resureksi Ilmu Pendidikan (Pedagogik) bagi Pemulihan Penyelenggaraan Pendidikan, (Bandung: Fak. Ilmu Pendidikan UPI, 2010), 3.

16 Dharma Kesuma, Cepti Triatna, dan Johar Permana, Pendidikan Karakter: Kajian Teori dan Praktik, (Bandung: PT Remaja Rosdakarya, 2012), 7-8.
} 
kontekstual. Selanjutnya yang kedua: pendidikan karakter memiliki sasaran untuk meluruskan berbagai prilaku yang negatif menjadi positif. Proses pedagogik dalam penelusuran yang dimaknai sebagai pengkoreksian perilaku negatif diarahkan pada pola fikir peserta didik, kemudian dibarengi dengan keteladanan lingkungan sekolah maupun rumah dan proses pembiasaan berdasarkan tingkat dan jenjang sekolahnya. ${ }^{17}$

Tujuan ketiga, memiliki makna bahwa pendidikan karakter disebuah lembaga pendidikan harus dihubungkan dengan proses pendidikan di keluarga. Jika pendidikan karakter di sekolah hanya bertumpu pada interaksi antar peserta didik dengan guru di kelas dan sekolah, maka pencapaian berbagai karakter yang diharapkan akan sangat sulit diwujudkan. Hal demikian itu disebabkan karena penguatan prilaku merupakan suatu hal yang menyeluruh (holistik) bukan suatu cuplikan dari rentangan waktu yang dimiliki oleh peserta didik. Dalam setiap menit dan detik interaksi anak dengan lingkungannya dapat dipastikan akan terjadi proses mempengaruhi perilaku anak, baik positif maupun negatif.

\section{Bimbingan Pribadi-Sosial}

W.S. Winkel memberikan definisi bahwa bimbingan pribadi sosial berarti bimbingan dalam menghadapi keadaan batinnya sendiri dan mengatasi permasalahan-permasalahan dalam hatinya sendiri, dalam mengatur dirinya sendiri di bidang seksual dan sebagainya, serta bimbingan dalam membina hubungan kemanusiaan dengan sesama di berbagai lingkungan pergaulan sosial. ${ }^{18}$

Berdasarkan pendapat di atas dapat dipahami bahwa bimbingan pribadisosial adalah sebuah layanan yang sangat urgen untuk diimplementasikan di sebuah instansi pendidikan (sekolah). Hal ini diorientasikan agar peserta didik bisa beradaptasi dan mampu bermasyarakat atau lebih tepatnya ia bisa bertahan dalam kehidupan di masyarakat secara praktis, karena kendatipun seorang siswa memiliki kecerdasan dibidang akademik tetapi ketika dihadapakan pada masyarakat secara praktis terkadang mereka cenderung merasa tidak siap dan tidak mampu berinteraksi dengan baik.

Bimbingan pribadi sosial adalah proses bimbingan yang difokuskan pada pengembangan pribadi, yaitu membantu siswa sebagai diri sendiri dan membantunya untuk mengenal dirinya, belajar menerima dirinya, dan belajar menerapkan dirinya dalam proses penyesuaian yang produktif terhadap lingkungannya. Sehingga dengan adanya layanan bimbingan pribadi sosial yang diberikan bisa membantu siswa untuk menerima dirinya sendiri dan dapat menyelesaikan berbagai macam persoalan yang dihadapi.

Layanan pribadi sosial di dalam ruang lingkup bimbingan dan konseling mempunyai landasan psikologis yaitu pribadi yang sehat. Selain landasan psikologis juga terdapat landasan sosial budaya yaitu kemajemukan etnis yang merupakan relita yang tidak mungkin diingkari. Selanjutnya yang harus diusahakan adalah bagaimana agar kemajemukan tersebut menjadi potensi yang menguntungkan bukan menimbulkan konflik yang merusak.19

\footnotetext{
17 Wibowo, Manajemen Pendidikan Karakter di Sekolah, (Yogyakarta: Pustaka Pelajar, 2013), 78.

18 W.S. Winkel, BK di Institusi Pendidika, (Jakarta: Gramedia Widiasarana, 1991), 127.

19. Achmad Juntika Nurihsan, Bimbingan dan Konseling dalam Berbagai Latar Kehidupan, Bandung: Refika Aditama, 2011), 1.
} 
Dalam penerapannya, layanan bimbingan konseling yang efektif dan efisien seharusnya merupakan tugas dan tanggung jawab bersama antara staf sekolah. Dalam arti lain, layanan bimbingan konseling merupakan tugas bersama atau kelompok (teamwork). Seluruh personil sekolah seharusnya ikut melibatkan diri secara aktif dalam semua kegiatan bimbingan konseling, mulai dari penyusunan kegiatan bimbingan konseling sampai pada tahap-tahap pelaksanaannya.20 Maka implementasi bimbingan dan konseling di sekolah bukan hanya menjadi tugas dan tanggung jawab pembimbing saja, akan tetapi lebih dari itu hal tersebut merupakan tugas seluruh kalangan yang terlibat secara langsung dalam proses kegiatan belajar mengajar (KBM) di sekolah sehingga melibatkan seluruh unsur yang ada merupakan sebuah keniscayaan yang seyogyanya perlu disinergikan.

\section{Tujuan Bimbingan Pribadi-Sosial}

Menurut Jamal ma'ruf Asmani, tujuan bimbingan pribadi sosial adalah:

1. Memiliki kemampuan untuk mengambil keputusan secara efektif.

2. Memiliki kemampuan dalam menyelesaikan konflik atau masalah baik yang bersifat internal (dalam diri sendiri) maupun eksternal (dengan orang lain).

3. Memiliki sikap positif atau respek terhadap diri sendiri dan orang lain.

4. Memiliki kemampuan berinteraksi sosial (human relatisionship), yang diwujudkan dalam bentuk hubungan persahabatan, persaudaraan atau silaturrahmi dengan sesame manusia. ${ }^{21}$

Berdasarkan pendapat diatas dapat dipahami bahwa bimbingan pribadi sosial bertujuan untuk mengembangkan kepribadian yang beriman kepada Tuhan yang Maha Esa, dapat membina hubungan kemanusiaan dengan sesama, dapat memahami irama kehidupan yang berubah-ubah, membangun atau mengarahkan kepribadian individu menjadi lebih baik dan peka terhadap sosial.

\section{Fungsi Bimbingan Pribadi-Sosial}

Penyelenggaraan bimbingan pribadi-sosial mengemban beberapa fungsi yang mengacu pada induknya bimbingan dan konseling. Fungsi-fungsi tersebut adalah fungsi pemahaman, fungsi pencegahan, fungsi pengentasan serta fungsi pemeliharaan dan pengembangan. ${ }^{22}$

a. Fungsi pemahaman adalah fungsi bimbingan dan konseling yang akan menghasilkan pemahaman tentang sesuatu oleh pihak-pihak tertentu sesuai dengan pengembangan siswa, pemahaman tersebut meliputi pemahaman diri dan pemahaman lingkungan.

b. Fungsi pencegahan (preventif) adalah fungsi bimbingan dan konseling yang akan menghasilkan terhindarnya siswa dari berbagai permasalahan yang mungkin timbul dan akan bisa mengganggu, menghambat ataupun menimbulkan kesulitan dan kerugian tertentu dalam proses perkembangan siswa.

\footnotetext{
20 Dewa Ketut Sukardi, Organisasi Administrasi di Sekolah, Surabaya: Usaha Nasional, 1993), 51.

21 Jamal Ma'mur Asmani, Panduan Efektif Bimbingan dan Konseling di Sekolah, (Yogyakarta: Diva Press, 2010), 54.

24 A. Juntika Nurihsan, Achmad Juntika Nurihsan, Bimbingan dan Konseling dalam Berbagai Latar Kehidupan, (Bandung: Refika Aditama, 2011), 8.
} 
c. Fungsi pengentasan adalah fungsi bimbingan dan konseling yang akan membantu teratasinya permasalahan yang dialami oleh siswa.

d. Fungsi pemeliharaan dan pengembangan adalah fungsi bimbingan dan konseling yang akan menghasilkan terpeliharanya dan berkembangnya berbagai potensi dan kondisi positif siswa dalam perkembangan dirinya secara mantap dan berkelanjutan.

Fungsi-fungsi tersebut hanya dapat terwujud dengan melalui terselenggarakannya berbagai jenis layanan bimbingan dan konseling di sekolah. Setiap layanan atau kegiatan bimbingan dan konseling yang akan dilaksanakan harus sesuai dan mengacu pada fungsi-fungsi bimbingan dan konseling agar pelaksanaaan dan terselenggarakannya sesuai dengan yang diidealkan, yaitu menciptakan peserta didik yang cerdas intelektual; mandiri, toleransi, dan dapat menerima diri sebagai makhluk Tuhan yang mempunyai berbagai macam potensi, serta cerdas spiritual; memiliki kometmen yang kuat dalam mengamalkan nilainilai keimanan dan ketakwaan kepada Tuhan Yang Maha Esa.

\section{Pembentukan Karakter Positif Siswa melalui Bimbingan Pribadi Sosial}

Membentuk karakter tidaklah semudah yang dibayangkan, kendati demikian yang namanya karakter tetap bisa dirubah. Karakter yang jelek bisa dirubah dengan karakter yang positif, demikian juga sebaliknya karakter yang positif bisa dirubah dengan karakter yang jelek, tergantung keinginan atau pengaruh dan usaha dari lingkungan atau tepatnya terletak pada kegigihan seorang pendidik (guru) dalam membentuk karakter siswa-siswanya dalam konteks pendidikan (sekolah).

Menurut pendekatan behavioristik, manusia dapat memiliki kecenderungan positif atau negatif karena pada dasarnya keperibadian manusia dibentuk oleh lingkungan dimana ia berada. Kaum behavioris lainnya seperti Albert Bandura menambahkan adanya faktor internal dalam diri individu yaitu kognitif (berpikir/belajar) yang lebih dikenal dengan teori belajar sosial (social learning). Teori Bandura menekankan hubungan antara perilaku, termasuk perilaku berpikir, dan konteks terjadinya perilaku itu.23 Dalam pandangannya, manusia pada hakikatnya makhluk yang berpikir dan sadar untuk mengatur tingkah lakunya. Manusia bukan pion atau bidak yang mudah dipengaruhi oleh lingkungan. Hubungan manusia dengan lingkungan bersifat saling mempengaruhi satu sama lain (reciprocal determinism.) 24 Dalam interaksinya dengan lingkungan ada proses berpikir (kognitif) yang kemudian menghasilkan respon (tingkah laku).

Artinya ada proses timbal balik yang berkesinambunngan antara kognitif, perilaku, dan pengaruh lingkungan yang diperoleh melalui proses pengamatan atau observasi. Belajar melalui pengamatan atau obervasi diatur oleh empat proses yang saling berkaitan: proses pemerhatian, retention (mengingat), reproduksi motorik (tindakan), dan motivasi.25

\footnotetext{
${ }^{23}$ Richard Nelson-Jones, Teori dan Praktek Konseling dan Terapi; Edisi Keempat, (Yogyakarta: Pustaka Pelajar, 2011), 450.

${ }^{24}$ Dede Rahmat Hidayat, Teori dan Aplikasi Psikologi Kepribadian dalam Konseling, (Bogor: Ghalia Indonesia, 2011), 150.

${ }^{25}$ Adang Hambali \& Ujam Jaenudin, Psikologi Kepribadian; lanjutan, (Bandung: Pustaka Setia, 2003), 159-160.
} 
Dari proses tersebut maka terciptalah suatu perilaku. Proses timbal balik tersebut dapat digambarkan sebagai berikut:

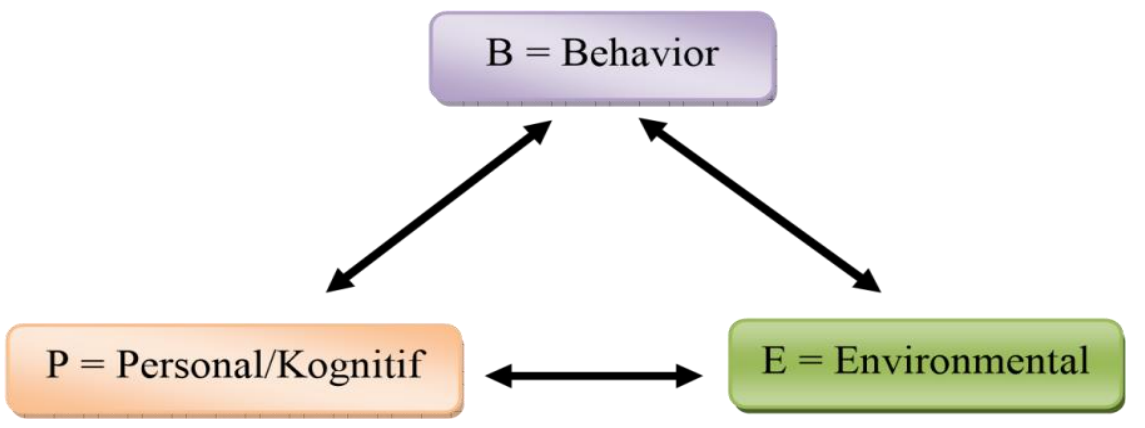

\section{Diagram reciprocaldeterminism antara personal (P) -- Environmental (E) --} Behavior (B). Sumber: Dede Rahmat Hidayat, Psikologi Kepribadian dalam Konseling (Bogor: Ghalia Indonesia, 2011).

Personal dalam konsep Bandura berbeda dengan konsep behavioralisme pada umumnya yang menempatkan manusia sebagai bidak yang tidak dapat melakukan suatu apapun tanpa stimulus dari luar. Bandura dalam social cognitive learning menempatkan manusia sebagai pribadi yang dapat mengatur diri sendiri (self regulation), mempengaruhi tingkah laku dengan cara mengatur lingkungan, menciptakan dukungan kognitif, mengadakan konsekuensi bagi tingkah lakunya sendiri.26 Sedangkan kognitif mencakup ekspektasi, keyakinan (self effication), strategi pemikiran dan kecerdasan.27 Kognitif memberi pedoman mekanisme sehingga individu berfikir dan membentuk keyakinan mampu atau tidak mampu mereka melakukan tindakan. Lingkungan sebagai model adalah berupa orang tua, guru, teman, dan masyarakat luas. Bagaimana hal itu semua mampu memberikan informasi berupa pemodelan (modeling). Tingkah laku merupakan hasil dari proses belajar dari lingkungan melalui pengamatan dan pemodelan. Tingkah laku akan mempengaruhi lingkungan dan lingkungan akan mempengaruhi pribadi/kognitif, antara pribadi, lingkungan dan tingkah laku terjadi hubungan timbal bailk yang terus menerus. 28

Pemberian informasi melalui modeling baik berupa verbal maupun non verbal harus disesuaikan dengan kondisi pribadi siswa agar proses pembentukan karakter dapat berjalan dengan yang diharapkan dan pembentukan karakter dapat terwujud. Kondisi pribadi siswa yang dimaksudkan adalah kondisi psikis siswa yang masih berada pada usia remaja, dan kondisi lingkungan sosial budaya pribadi siswa.

Pribadi siswa yang baik akan dengan mudah menerima informasi yang baik dari lingkungan dan akan membentuk tingkah laku yang baik. Anak pada umumnya sejak dari bayi bahkan sejak dalam kandungan sudah ditanamkan halhal yang baik, sehingga ketika sekolah memberikan informasi yang baik akan mudah

\footnotetext{
${ }^{26}$ Hayati, Ayasipelita, “Teori-Sosial-Kognitif-dari-Albert-Bandura," dalam http://.wordpress.com/2010/04/08. Akses tanggal 17 Februari 2018.

27 Ikhlasia, "Materi-Kuliah/Teori-Albert-Bandura," dalam http://.wordpress.com. Akses tanggal 17 Februari 2018.

${ }^{28}$ Adang Hambali \& Ujam Jaenudi, Psikologi Kepribadian; Lanjutan, (Bandung: Pustaka Setia, 2013), 155.
} 
diterima. Hal tersebut tentunya akan berimplikasi pada pembentukan karakter yang baik pula.

Hal tersebut dapat dipahami bahwa perilaku, lingkungan dan pribadi individu saling mempengaruhi satu sama lain (timbal-balik). Pribadi menerima informasi dari lingkungan kemudian ada proses perfikir dan membentuk tingkah laku. Tingkah laku akan mempengaruhi lingkungan yang kemudian membentuk pribadi. Selain rangsangan dari luar mempengaruhi perilaku individu, faktor pribadi seperti keyakinan dan harapan mempengaruhi bagaimana individu berperilaku. Sekuat apapun lingkungan (keluarga, sekolah, masyarakat) mempengaruhi individu tetapi tidak ada respon (keinginan dan keyakinan) dari diri individu tersebut untuk meniru, maka proses pembentukan karakter (tingkah laku, pola pikir) tidak akan terwujud. Sebagaimana firman Allah dalam Q.S. Ar Ra'd [13]: 11.

Artinya; "Bagi manusia ada malaikat-malaikat yang selalu mengikutinya bergiliran, di muka dan di belakangnya, mereka menjaganya atas perintah Allah. Sesungguhnya Allah tidak merubah keadaan sesuatukaum sehingga mereka merubah keadaan yang ada pada diri mereka sendiri. dan apabila Allah menghendaki keburukan terhadap sesuatu kaum, Maka tak ada yang dapat menolaknya; dan sekali-kali tak ada pelindung bagi mereka selain Dia".

Selain hal tersebut, Nabi Muhammad SAW juga menekakankan betapa sangat pentingnya pengaruh lingkungan terhadap diri manusia (siswa) dalam sabdanya:

"Tidak ada seorang anakpun yang lahir, kecuali ia dilahirkan atas fitrah. Kedua orang tuanyalah yang menjadikan dia beragama yahudi, nasrani ataupun beragama majusi sebagaimana binatang ternak memperanakkan seekor binatang (yang sempurna anggota tubuhnya). Apakah kalian mengetahui di antara binatang itu ada sesuatu yang putus (telinganya atau anggota tubuhnya yang lain). Kemudian Abu Hurairah berkata: bacalah, jika kamu menghendakinya (Maka hadapkanlah wajahmu dengan lurus kepada agama (Allah); (tetaplah atas) fitrah Allah yang telah menciptakan manusia menurut fitrah itu. Tidak ada perubahan pada fitrah Allah. (Itulah) agama yang lurus; tetapi kebanyakan manusia tidak mengetahui)”.

Fitrah yang dimaksudkan adalah manusia bukan kertas putih (kosong) tanpa goresan apapun sebagaimana teori tabularasa dari John Lock. Menurut M.D Dahlan (2003), fitrah manusia adalah terdiri dari fitrah jasmani, rohani dan nafs (kalb, akal, dan nafsu). ${ }^{29}$ Fitrah tersebut akan tumbuh dan berkembang dengan optimal apabila ada stimulus dari lingkungan.

Fitrah (potensi) merupakan kemampuan dasar manusia yang masih bersifat sederhana, untuk menumbuhkan dalam bentuk aplikatif praktis, maka pemberian rangsangan melalui proses pendidikan melalaui pemberian layanan bimbingan dan konseling harus dilakukan dengan tepat dan cermat karena kesalahan pemberian stimulus akan menghambat perkembangan potensi anak dan juga

\footnotetext{
${ }^{29}$ Anwar Sutoyo, Bimbingan dan Konseling Islami; Teori dan Praktik, (Semarang: Widya Karya, 2009), 59.
} 
dapat mengarah kepada hal yang lebih fatal. Potensi anak akan tumbuh dan berkembang sesuai dengan pengaruh lingkungan alam sekitarnya dimana ia berinteraksi. Oleh karena itu bimbingan dan konseling mempunyai peranan yang sangat urgen dalam mengasah dan mengembangkan potensi peserta didik.

Dapat dipahami bahwa karakter positif akan terbentuk apabila lingkungan peserta didik dapat memberikan stimulus yang kontinyu agar terjadi respon dari peserta didik dengan cara penanaman nilai-nilai karakter yang baik, keteladanan, dan pembiasaan. Artinya guru bimbingan dan konseling tidak hanya memberikan bimbingan secara verbal tetapi juga secara non-verbal, yaitu berupa tingkah laku dan tutur kata yang baik (teladan), yang dalam hal ini guru sebagai model. Perilaku dihasilkan dari pengalaman yang diperoleh individu dalam interaksinya dengan lingkungan. Kebanyakan perilaku manusia adalah hasil belajar dari model (guru, keluarga, masyarakat) bukan melalui proses pengkondisian klasik dan instrumental.30

Pembentukan karakter positif pada peserta didik di sekolah idealnya adalah tugas semua pihak terutama guru. Dalam hal ini, peran dan fungsi guru bimbingan dan konseling sangat dibutuhkan, terutama melalui bimbingan pribadi sosial sehingga peserta didik menjadi percaya diri, cerdas/ tepat dalam menentukan pilihan, bisa mengatasi atau mencari solusi dalam sebuah persoalan, menjalin komunikasi yang baik dengan teman sebaya dan orang lain, bertanggung jawab dalam semua tindakan dan lain sebagainnya.

\section{Penutup}

Karakter dapat dibentuk dan bisa dirubah, karakter yang jelek bisa dirubah menjadi karakter yang positif, demikian juga sebaliknya karakter yang positif bisa dirubah menjadi karakter yang jelek, tergantung keinginan atau pengaruh dan usaha dari lingkungan, dalam hal ini kegigihan seorang pendidik (guru) dalam membentuk karakter anak didiknya dalam konteks pendidikan (sekolah) merupakan sebuah keniscayaan. Agar tujuan layanan bimbingan pribadi sosial dapat direalisasikan sebagaimana yang diidealkan, maka pembentukan karakter positif siswa di sekolah melalui bimbingan pribadi sosial dapat dilakukan melalui kerja sama yang sinergis antara guru bimbingan dan konseling dengan semua elemen yang ada di sekolah, orang tua siswa, dan masyarakat.

\section{Daftar Pustaka}

Asmani, Jamal Ma'mur. Panduan Efektif Bimbingan dan Konseling di Sekolah, (Yogyakarta: Diva Press, 2010)

BAPPENAS ARAHAN RPJPN 2005-2025.

Chatib, Munif. Sekolahnya Manusia, (Bandung: Mizan, 2011)

C. Scerenko, Linda. Values and Character Education Implementation Guide, Gerogia: Departement of Education, 1997.

Hambali, Adang. \& Jaenudi, Ujam. Psikologi Kepribadian; Lanjutan, (Bandung: Pustaka Setia, 2013)

\footnotetext{
30 Dede Rahmat Hidayat, Teori dan Aplikasi Psikologi Kepribadian dalam Konseling, (Bogor: Ghalia Indonesia, 2011),159.
} 
Hayati, Ayasipelita, "Teori-Sosial-Kognitif-dari-Albert-Bandura,"

dalam http://.wordpress.com/2010/04/08. Akses tanggal 17 Februari 2014.

Hidayat Rahmat, Dede. Teori dan Aplikasi Psikologi Kepribadian dalam Konseling, (Bogor: Ghalia Indonesia, 2011.

Ikhlasia, "Materi-Kuliah/Teori-Albert-Bandura," dalam http://.wordpress.com. Akses tanggal 17 Februari 2014.

Juntika Nurihsan, Achmad. Bimbingan dan Konseling dalam Berbagai Latar Kehidupan, (Bandung: Refika Aditama, 2011)

Kesuma, Dharma. Triatna, Cepti. dan Permana, Johar. Pendidikan Karakter: Kajian Teori dan Praktik, (Bandung: PT Remaja Rosdakarya, 2012)

Kartadinata, Sunaryo. Resureksi Ilmu Pendidikan (Pedagogik) bagi Pemulihan Penyelenggaraan Pendidikan, (Bandung: Fak. Ilmu Pendidikan UPI, 2010)

Koesoema, Dony. Pendidikan Karakter, (Jakarta: Kompas Gramedia, 2007)

Majid, Abdul. \& Andayanik, Dian. Pendidikan Karakter Persepektif Islam, (Bandung: PT. Rosda Karya, 2012)

Mu'in, Fatchul. Pendidikan Karakter Konstruksi Teoritik \& Praktik, (Yogyakarta: ArRuzz Media, 2011)

Nelson-Jones, Richard. Teori dan Praktek Konseling dan Terapi; Edisi Keempat, (Yogyakarta: Pustaka Pelajar, 2011)

Penisula, Menara. Desain Pendidikan Karakter Kementerian Pendidikan Nasional 2010.

Poerwadarminta, W.J.S. Kamus Umum Bahasa Indonesia, (Jakarta: Balai Pustaka, 2005)

Siregar, Maragustam. dalam catatan mata kuliah: Filsafat Pendidikan Islam, 20 November, 2012. , Mencetak Pembelajar Menjadi Insan Paripurna: Falsafah Pendidikan Islam, (Yogyakarta: Nuha Litera, 2010) dalam pidato ilmiah dalam acara pengukuhan guru besarnya, di rapat senat terbuka Univirsitas Islam Negeri Sunan Kalijaga Yogyakarta. Tanggal 23 Oktober 2012.

Sukardi, Dewa Ketut. Organisasi Administrasi di Sekolah, (Surabaya: Usaha Nasional, 1993)

Sutoyo, Anwar. Bimbingan dan Konseling Islami; Teori dan Praktik, (Semarang: Widya Karya, 2009)

Suyanto \& Hisyam, Djihad. Pendidikan di Indonesia Memasuki Melenium III, (Yogyakarta: Adicita Karya Nusa, 2000)

Undang-Undang tentang Sistem Pendidikan Nasional, No. 20 Tahun 2003.

Wibowo, Agus. Manajemen Pendidikan Karakter di Sekolah, (Yogyakarta: Pustaka Pelajar, 2013)

Winkel, W.S. Bimbingan dan Konseling di Institusi Pendidikan, (Jakarta: PT. Grasindo, 1997)

Winton, Sue. "Character Education: Implication for Critical Democracy", International Critical Childhood Policy Studies, Vol. I (I), 2008.

Wiyani, Novan Ardy. Manajemen Pendidikan Karakter, Konsep dan Implementasinya di Sekolah, (Yogyakarta: Pustaka Insan Madani, 2010) 